\title{
The Biochemical Evaluation of Aquaculture Nile Tilapia Muscle Tissue, in Condition of Some Phytobiotics Administered in Feed
}

\author{
Alina ANTACHE*, Victor CRISTEA, Lorena DEDIU, Iulia GRECU, Stefan M. PETREA, Alexandru C. BANDI \\ Department of Aquaculture, Environmental Science and Cadastre, University "Dunarea de Jos" Galati, Romania \\ *Corresponding author, email: antache_alina@yahoo.com
}

Bulletin UASVM Animal Science and Biotechnologies 72(1) / 2015

Print ISSN 1843-5262; Electronic ISSN 1843-536X

DOI:10.15835/buasvmcn-asb:10387

\begin{abstract}
The purpose of this research was to determine the effect of some phytobiotics on biochemical composition of Nile tilapia muscle tissue reared in a recirculating aquaculture system. The experiment was conducted for fourteen weeks, from August 17 to November 27, 2012. The experimental variants were: V1-control, V2-1\% Rosmarinus officinalis/kg feed; V3-1\% Hippophae rhamnoides/kg feed and V4-1\% Zingiber officinale $/ \mathrm{kg}$ feed. During the experiment, the sampling for biochemical analysis of muscle tissue was performed at the beginning of the experiment (17.08.2012), on intermediary moment (28.09.2012) and at the end of the experiment (27.11.2012), from fresh meat. The results showed significant differences $(\mathrm{p}<0.05)$ both between initial $(\mathrm{Vi})$ and intermediary (Vint- 28.09.2012) moment and between experimental variants (Vint) in terms of protein, fat, moisture and dry matter percentage. At the end of the experiment were registered significant differences $(p<0.05)$ with respect to protein and moisture percentage. Also, in this paper is presented the dinamics of nutrient retention efficiency (PER-g/g, PUE-\%, RP-g/fish and RL-g/fish) at Nile tilapia, in the muscle tissue. At the intermediary moment, in V3 was registered the lowest value of fat content (1.22\%), and in V4 the highest value of protein content (13.11\%). In conclusion, rosemary, sea buckthorn and ginger, in concentration of $1 \% / \mathrm{kg}$ feed, influenced significantly the biochemical composition of muscle tissue at Oreochromis niloticus species.
\end{abstract}

Keywords: biochemical composition of muscle tissue, Oreochromis niloticus, phytobiotics recirculating aquaculture system

\section{INTRODUCTION}

Determination of biochemical composition of fish meat is a very important aspect because it is well known the role of fish meat in the human diet. Fish meat is renowned for the its nutritional value due to the rich content of nutrients as well as protein, essential amino acids, in particular lysine, methionine and cysteine, lipids -fatty acids such as omega, carbohydrates, vitamins and minerals (Ćirković et al., 2002; Ferraz de Arruda et al., 2006; Sandor et al., 2011). At the same time, it is also known that the fish meat protein is digested more easily than any other animal proteins (Sandor et al., 2011). Good digestibility of fish meat comes from the content of short muscle fibers, lacks of scleroproteins, collagen and elastin (Ćirković et al., 2002).
Composition of fish proteins is better than the composition of proteins of other animals, which is mainly due to more favorable amino acid composition and lot of free amino acids (Tope et al., 2007; Buchtová et al., 2010). High biological value of fish proteins results from the presence of small content of connective tissue and lack of fascia and aponeurosis. Fish proteins contain all the essential amino acids for the human organism and they can be used as the sole source of protein (Vladau et al., 2009).

Biochemical composition of fish meat is influenced by numerous of endogenous and exogenous factors, but depends mostly by the biochemical composition of feed administered (Hernández-Sánchez and Aguilera-Morales, 2012; Alemu et al., 2013). Among the endogenous 
factors enumerated in particular the age and sex, although some researchers say that fish sex would not lead to significant changes in the biochemical composition of meat (Cornelia, 2012).

Phytobiotics are herbal plants or derived from plants, which contain a wide range of natural bioactive compounds. In recent years, the phytobiotics administration in feed of different animal species increased.

The aim of this research was to investigate the influence of Rosmarinus officinalis, Hippophae rhamnoides and Zingiber officinale on biochemical composition of Oreochromis niloticus muscle tissue, reared in an intensive recirculating aquaculture system conditions.

\section{MATERIALS AND METHODS}

The experiment was conducted during a fourteen weeks, from August 17 to November 27, 2012 in the pilot recirculating system of Aquaculture, Environmental Science and Cadastre Department from "Dunarea de Jos" University, Galati.

The recirculating system design includes four rearing units, with a volume of $1 \mathrm{~m}^{3}$ each, and a series of water quality conditioning units (Cristea et al., 2002). The conditioning units for water quality are designed to maintain in an optimum range the main physical-chemical parameters of the water: oxygen content, temperature and $\mathrm{pH}$.

A total number of 168 of Nile tilapia, with an initial average weight of $280.07 \pm 54.03 \mathrm{~g} /$ fish, were randomly distributed in 4 rearing units. Fish were fed with SOPROFISH pelleted feed, with $38 \%$ crude protein and $7 \%$ crude lipid. The feed biochemical composition is presented in the paper of Antache et al. (2013). Fish were fed four times per day $(09: 00,12: 00,15: 00,18: 00)$ with a daily ration of $2 \%$ from fish body weight.

During the experiment, the feed was supplemented with three phytobiotics (rosemaryRosmarinus officinalis, sea buckthorn-Hippophae rhamnoides and ginger-Zingiber officinale), in concentration to $1 \%$. Thus, the experimental variants were organized as follows: V1-control, V2$1 \%$ rosemary $/ \mathrm{kg}$ feed, V3-1\% sea buckthorn $/ \mathrm{kg}$ feed and V4-1\% ginger $/ \mathrm{kg}$ feed. The introduction of phytobiotics in feed was performed using an aqueous solution of gelatin with $2 \%$ concentration.

The sampling for biochemical analysis of muscle tissue was performed at the beginning of the experiment (17.08.2012), on intermediary moment (28.09.2012) and at the end of the experiment (27.11.2012). When collecting the samples, the uniformity of exemplars was taken into account to eliminate the errors, which consist in weight differences between exemplars. The biochemical determinations were performed from fresh muscle tissue samples. The samples were weighed and minced in a tissue grinder to ensure homogeneous samples for the analysis. The proximate composition of meat was carried out using the Association of Analytical Chemists methods (AOAC).

For the analysis of Oreochromis niloticus meat biochemical composition was performed to determine the body percentage of moisture, protein content, fat content, ash and dry matter.

Proteins were determined with Gerhardt equipment by using Kjeldahl method, fats were determined by Soxhlet solvent extraction method (petroleum ether) with Raypa extraction equipment, dry matter was determined by heating at temperature of $105 \pm 2{ }^{\circ} \mathrm{C}$ using Sterilizer Esacand ash was evaluated by calcification at temperatures of $550 \pm 20^{\circ} \mathrm{C}$, in a Nabertherm furnace.

The technological indicators of fish rearing involved the biochemical composition of fish muscle tissue are: retained protein (RP), protein efficiency ratio (PER), protein utilization efficiency (PUE) and retained lipids (RL). These indicators were calculated based on following formulas:

Protein efficiency ratio (PER):

$$
[\mathrm{PER}]=(\mathrm{Bf}-\mathrm{Bi}) /(\mathrm{FxPb})(\mathrm{g} / \mathrm{g}) \text {, }
$$

where: Bi-initial body weight (g); Bf-final body weight (g); F-quantity of feed administrated $(\mathrm{g})$; $\mathrm{Pb}$-protein quantity from feed $(\%)$.

Protein utilisation efficiency:

$$
[\mathrm{PUE}]=100(\mathrm{Bf} \times \mathrm{Pf}-\mathrm{Bi} \times \mathrm{Pi}) /(\mathrm{F} \times \mathrm{Pb})(\%)
$$

where: Pf-final body protein (\%); Pi-initial body protein (\%).

Retained protein (RP):

$$
[\mathrm{PR}]=\mathrm{Bf} \times \mathrm{Pf}-\mathrm{Bi} \times \mathrm{Pi}(\mathrm{g} / \mathrm{fish})
$$


Retained lipids (RL):

$$
[\mathrm{RL}]=\mathrm{Bf} \times \mathrm{Lf}-\mathrm{Bi} \times \mathrm{Li}(\mathrm{g} / \mathrm{fish})
$$

where: Lf-final body lipids (\%); Li-initial body lipids (\%).

The data were statistically analyzed using descriptive statistics and ANOVA One Way test. Programs used were Microsoft Excell (Office 2010) and SPSS Statistics 20.0 for Windows. The results are presented as mean \pm standard error.

\section{RESULTS AND DISCUSSION}

The biochemical composition of meat varies considerably, depending on several factors like: fish age, size, sex, environmental conditions (temperature, dissolved oxygen, $\mathrm{pH}$, salinity, etc), feeding mode and the type of used feed (Hernandez-Sanchez and Aguilera-Morales, 2012).

During the experiment, the physicalchemical parameters of technological water were situated into normal range for optimal growth: D0 $-7.66 \pm 1.36 \mathrm{mg} / \mathrm{L}, \quad \mathrm{T}-26.87 \pm 0.29^{\circ} \mathrm{C}$, $\mathrm{pH}-7.56 \pm 0.20, \quad \mathrm{~N}-\mathrm{NO}_{2}-0.16 \pm 0.06 \mathrm{mg} / \mathrm{L}, \quad \mathrm{N}-\mathrm{NO}_{3}-$ $176.89 \pm 57.24 \mathrm{mg} / \mathrm{L}, \quad \mathrm{N}-\mathrm{NH}_{4}-0.16 \pm 0.09 \mathrm{mg} / \mathrm{L}$ (Masser et al., 1999; Ridha, 2006; Khalafalla, 2008).

The average individual weight values obtained during the experiment are shown in Table 1.

The values of main biochemical parameters: moisture (\%), protein content (\%), fat content $(\%)$ and ash (\%) from Nile tilapia muscle tissue, reared in a recirculating aquaculture system are presented in Figure 1.

Biochemical analysis of muscle tissue showed significant differences $(\mathrm{p}<0.05)$ in statistical terms, between initial and intermediary moment in terms of protein $(p=0.046)$, fat $(p=0.002)$, moisture $(p=0.016)$ and dry matter percentage $(\mathrm{p}=0.001)$. At the end of the intermediary stage (28.09.2012), between the experimental variants were recorded significant differences $(p<0.05)$ also in case of protein $(\mathrm{p}=0.000)$, fat $(\mathrm{p}=0.016)$, moisture $(p=0.024)$ and dry matter percentage content $(p=0.007)$. The protein content from the tissue samples ranged from $12.52 \%$ to $13.11 \%$ and the highest value was obtained in variant in which the diet was supplemented with ginger (V4 $-13.11 \pm 0.11 \%)$. The highest value of moisture was registered in variant V3 $(84.76 \pm 0.10 \%)$ and the lowest in variant V4 (84.20 $\pm 0.06 \%)$. Concerning fat content, the lowest value was registered in V3 $(1.22 \pm 0.02 \%)$ and the highest was reported in V1 $(1.62 \pm 0.08 \%)$.

In the case of ash percentage were not recorded significant differences $(p<0.05 ; p=0.663)$ between the experimental variants. The highest value of ash content was recorded in variant V1 $(1.35 \pm 0.04 \%)$ and the lowest in variant V4 $(1.27 \pm 0.03 \%)$.

In terms of dry matter (\%), between experimental variants were recorded significant differences $(\mathrm{p}<0.05 ; \mathrm{p}=0.007)$. The lowest value were registered in variant V3 $(22.69 \pm 0.25 \%)$ and the highest in variant V1 (25.22 $\pm 0.17 \%)$ (Fig. 2).

At the end of the experiment between the experimental variants were significant differences $(p<0.05)$ only in case of protein $(\%)(p=0.003)$ and moisture content $(\%)(p=0.000)$. The highest value of protein (\%) was registered in variant V1 $(13.59 \pm 0.07 \%)$ and the lowest value in variant V3 $(12.62 \pm 0.02 \%)$. In terms of moisture (\%) in variant V1 $(83.76 \pm 0.36 \%)$ was obtained the lowest value and the highest value was obtained in variant V3 $(85.14 \pm 0.27 \%)$.

Tab. 1. The average individual weight values ( $\mathrm{g} /$ fish) obtained during the experiment

\begin{tabular}{cccc}
\hline \multicolumn{1}{l}{ Initial $(17.08 .2012)$} & & \\
\hline $280.07 \pm 54.03$ & & & \\
\hline $\mathrm{V} 1$ & $\mathrm{~V} 2$ & $\mathrm{~V} 3$ & $\mathrm{~V} 4$ \\
\hline Intermediary $(28.09 .2012)$ & & & \\
\hline $455.43 \pm 89.17$ & $446.00 \pm 73.95$ & $466.26 \pm 65.33$ & $461.48 \pm 71.76$ \\
\hline Final $(27.11 .2012)$ & & & \\
\hline $596.68 \pm 115.19$ & $588.83 \pm 91.75$ & $619.45 \pm 84.87$ & $616.43 \pm 104.71$ \\
\hline
\end{tabular}



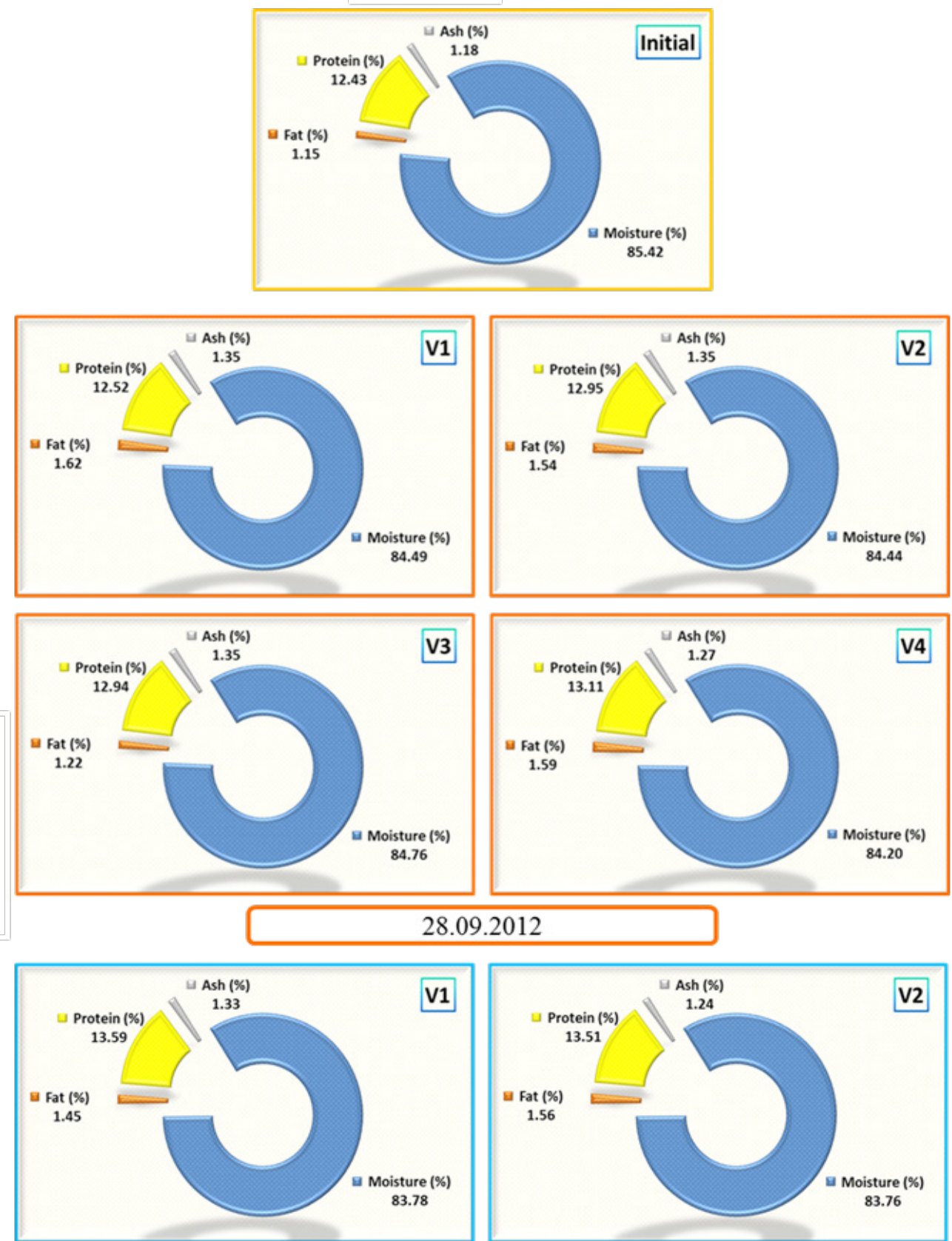

8.09 .2012
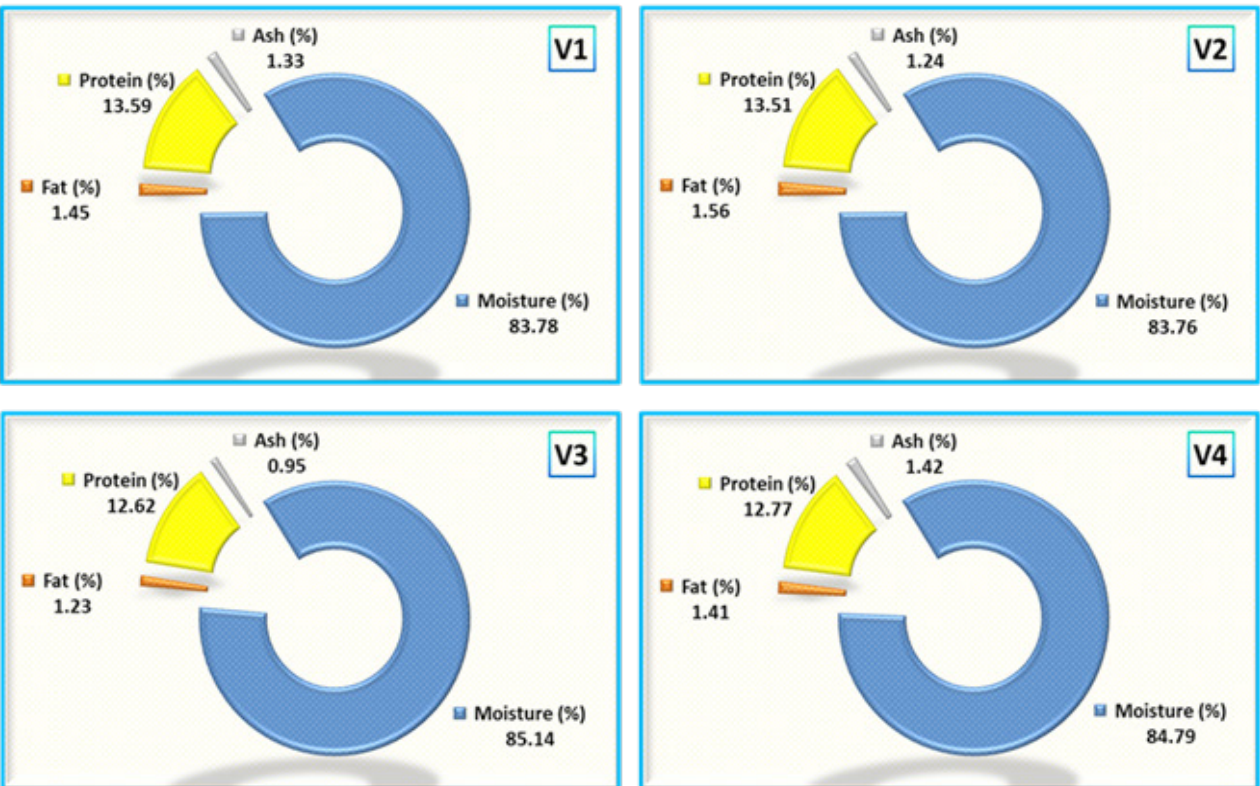

27.11.2012

Fig. 1. The biochemical composition of Oreochromis niloticus muscle tissue, fed with some phytobiotics Note: V1 - control, V2 - 1\% rosemary, V3 - 1\% sea buckthorn, V4 - 1\% ginger 


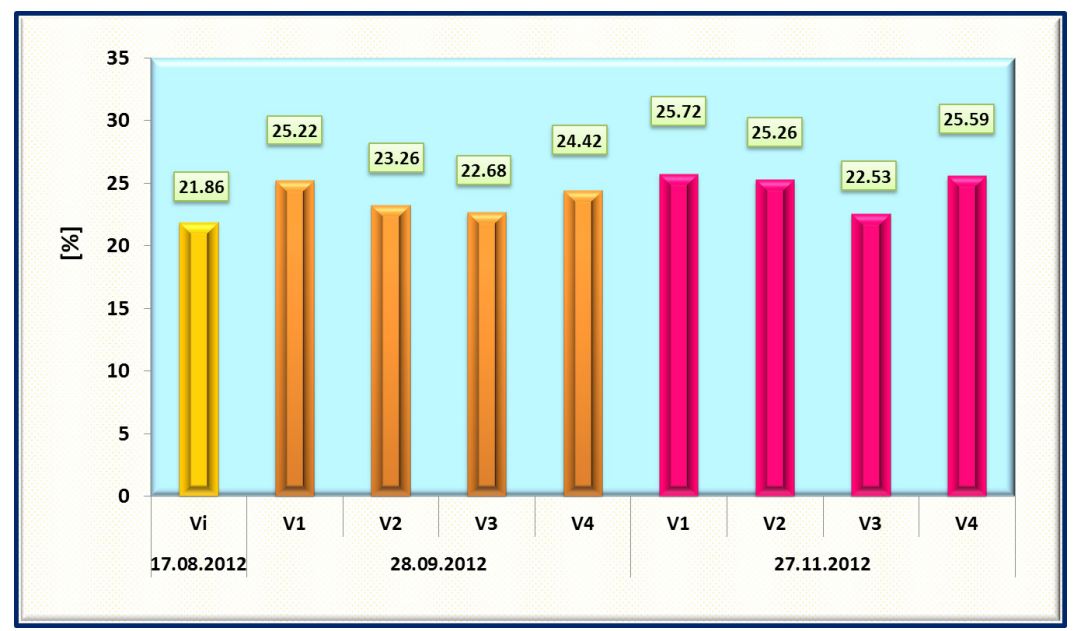

Fig. 2. The content of dry matter percentage obtained during the experiment

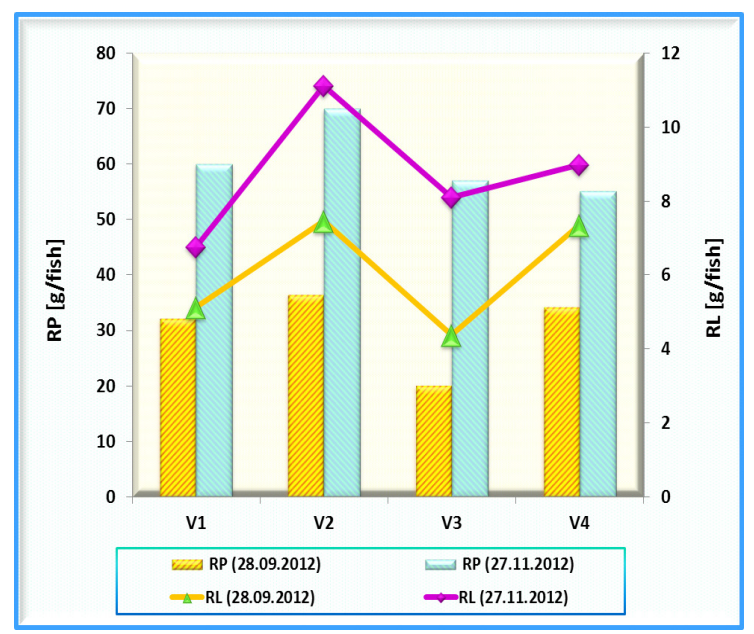

Fig. 3. Dynamic of retained protein (RP) and retained lipid (RL) during the experiment

In terms of dry matter (\%), at the end of the experiment there were not registered significant differences $(\mathrm{p}<0.05)$ between the experimental variants $(p=0.468)$, and neither between initial value, intermediary and final values $(p=0.131)$. Comparing the values obtained at the end of the experiment with initial values (Vi) and intermediary values (28.09.2012) were recorded significant differences $(\mathrm{p}<0.05)$ in case of fat $(\%)$ $(p=0.012 ; 0.004)$, protein $(\%)(p=0.007 ; 0.000)$ and moisture $(\%)$ content $(\mathrm{p}=0.002 ; 0.000)$.

Determination of technological indicators RL, RP, PER and PUE revealed at the end of the experiment more aspects. The lowest values of retained lipids was obtained in V3, but also in V1 variant at the end of the experiment but also at the end of the intermediary stage.

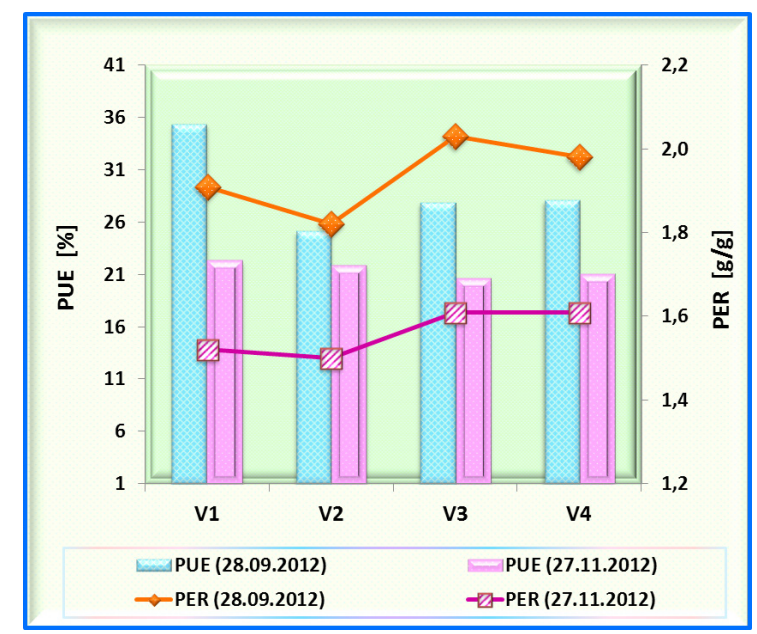

Fig. 4. Dynamic of PUE and PER indicators

The retained proteins (RP) show lower values in variants V3 and V4. Regarding retained protein and lipid, the values obtained can be seen in Figure 3. Also, even if was obtained a greater quantity of retained protein (RP) in variant V2, it can be seen that ingested proteins were not effectively used to enhance growth rate of biomass because PER indicator recorded during the experiment the best values especially in variant V3, respectively in variant V4 compared to the results obtained in variants V2 and V1. Therefore, the proteins utilization efficiency (PUE) has been higher in V3, but also in variant V4, fact confirmed by obtaining a higher biomass growth than in V1 and V2 variant (Fig. 4).

Our result obtained after analysis of biochemical composition of muscle tissue at Nile tilapia 
are found within optimal ranges described in the literature for Oreochromis niloticus species. Thus, for the moisture content (\%)the range is between $80.50 \%$ and $84.00 \%$ (Abd-Alla, 1994), for the lipid content (\%) values are in the interval $0.7 \%$ and 8.5\% (Visentainer et al. 2005), for the ash content (\%) was reported a range between 0.5 and $1.5 \%$ (Hernandez-Sanchez and Aguilera-Morales, 2012). For the protein content (\%) Sultana et al. (2012) reported an optimal range between $10.19 \%$ and $13.32 \%$ in case of feed supplemented with some phytobiotics.

Following analyzes performed, was observed that in variant V3, in which was administered sea buckthorn, along with reducing the percentage of fat in muscle tissue has been an increase in the percentage of moisture. This aspect was also reported when the diet of Oreochromis niloticus was supplemented with Moringa oleifera (Richter et al., 2003).

\section{CONCLUSION}

If in case of rosemary and ginger administration the results showed a fluctuation depending on the duration of phytobiotics administration, in case of sea buckthorn (V3) the results revealed the same trend in terms of fat (\%), moisture (\%) and dry matter (\%) content from Nile tilapia muscle tissue, both the after 6 weeks as well as after 14 week administration.

Regarding the protein (\%) and ash (\%) content, in V3 the values registered were higher after 6 weeks of administration than those obtained at the end of the experiment (after 14 weeks).

During the experiment can be seen that the ginger administration led to a reduction in moisture (\%) and an increase in proteins (\%) content of muscle tissue after 6 weeks compared to the other experimental variants. However, this aspect cannot be confirmed after 14 weeks.

Regarding the rosemary administration may notice an improvement in biochemical composition of Nile tilapia muscle tissue after 14 weeks of administration. This shows that for obtaining positive changes in biochemical composition of Nile tilapia muscle tissue the administration of $1 \%$ rosemary $/ \mathrm{kg}$ feed should be done over a longer period or to establish a different concentration of administration. Perhaps the concentration used was lower or higher.
In conclusion, for obtaining the expected results the sea buckthorn and even ginger administration in 1\% concentration must be achieved in a shorter of time (in our case 6 weeks).

Acknowledgments. The work of Alina Antache and Stefan Mihai Petrea has been funded by the Sectoral Operational Programme Human Resources Development 2007-2013 of the Ministry of European Funds through the Financial Agreement POSDRU/159/ 1.5/S/132397ExcelDOC.

\section{REFERENCES}

1. Abd-Alla Soa (1994). Technological and chemical studies on some fish cultures. Ph.D. Thesis, Fac. Agric., Zagazig, Egypt.

2. Alem, LA, AY Melese and DH Gulelat (2013). Effect Of Endogenous Factors On Proximate Composition Of Nile Tilapia (Oreochromis Niloticus L.) Fillet From Lake Zeway. American Journal of Research Communication 1(11): 405-410.

3. Antache A, V Cristea, L Dediu, I Grecu, A Docan, I Vasilean, M Mocanu (Crețu) and Șt M Petrea (2013). The influence of some phytobiotics on growth performance at Oreochromis niloticus reared in an intensive recirculating aquaculture system. Lucrări Ştiințifice-Seria Zootehnie, 60:204-208.

4. Association of Official Analytical Chemists (AOAC), 17th Edition, A.O.A.C., Washington DC, 2000, 21: 447.

5. Buchtová H, Z Svobodová, M Kocour and J Velíšek (2010). Chemical Composition of Fillets of Mirror Crossbreds Common Carp (Cyprinus carpio L.). Acta Veterinaria Brno 79: 551-557.

6. Ćirković M, B Jovanović and S Maletin (2002). Ribarstvo. Univerzitetu Novom Sadu. Poljoprivredni fakultet.

7. Cornelia $A B$ (2012). Investigation of the chemical composition and nutritional value of smoothhound shark (Mustelus mustelus) meat. Thesis presented in partial fulfillment of the requirements for the degree Master of Science in Food Science at the University of Stellenbosch.

8. Cristea V, I Grecu and C Ceapa (2002). Recirculating aquaculture systems engineering. Didactic and Pedagogic Publishing House, R. A. Bucharest.

9. Ferraz De Arruda, L, R Borghesi, A Brum, MR D’Arce and M Oetterer (2006). Nutritional Aspects of Nile Tilapia (Oreochromis Niloticus) Silage. Ciênc. Tecnol. Aliment, Campinas 26(4): 749-753.

10. Hernandez-Sanchez F and ME Aguilera-Morales (2012). Nutritional richness and importance of the consumption of tilapia in the Papaloapan Region. REDVET 13(6). http:// www.veterinaria.org/revistas/redvet/n060612/061205. pdf

11. Khalafalla ME (2009). Utilization of Some Medical Plants as Feed Additives for Nile Tilapia, Oreochromis niloticus, feeds. Mediterranean Aquaculture Journal. 2(2): 10-19. 
12. Masser MP, J Rakocy and TM Losordo (1999). Recirculating Aquaculture Tank Production Systems, Management of RecirculatingSystems. SRAC Publication No.452.

13. Richter N, P Siddhuraju and K Becker (2003). Evaluation of nutritional quality of moringa (Moringa opeieralam) leaves as an alternative protein source for Nile tilapia (Oreochromis niloticus). Aqua. 599-611.

14. Ridha TM (2006). Comparative study of growth performance of three strains of Nile tilapia, Oreochromis niloticus L. At two stoking densities, Aquacul. res. 37: 172-179.

15. Sandor Z, Z Gy Papp, I Csengeri and Z Jeney (2011). Fish meat quality and safety, Tehnologija mesa 52(1): 97-105.

16. Sultana N, P Noor, ATM Abdullah, MR Hasan, KM Ahmed and MN Naser (2012). Growth Performance and Nutrient
Composition of JuvenileNile Tilapia (Oreochromis niloticus) Fed Spirulina Flakes,Rice Bran and Mustard Oil Cake. Mal. J. Nutr. 18(2): 275 - 282.

17. Toppe J, S Albrektsena, B Hopea and A Anders (2007). Chemical composition. mineral content and amino acid and lipid profiles in bones from various fish species. Comparative Biochemistry and Physiology. Part B: Biochemistry and Molecular Biology 146(3): 395-401.

18. Vladau VV, I Bud and R Stefan, 2008. Nutritive value of fish meat comparative to some animals meat. Bulletin UASVM Animal Science and Biotechnologies 65(1-2): 301-305.

19. Visentainer JV, NE Souza, M Makoto, C Hayashi and MRB Franco (2005). Influence of diets enriched with flaxseed oil on the a linolenic, eicosapentaenoic and docosahexaenoic fatty acid in Nile tilapia (Oreochromis niloticus). Food Chemistry 90: 557-560. 